\title{
The Perception of Critical Success Factors for PPP Projects in Different Stakeholder Groups
}

\author{
Joanna Węgrzyn
}

\begin{abstract}
A B S T R A C T
Objective: The main goal of the research is to enhance understanding which factors are perceived as critical for the success of public-private partnerships (PPPs) by different stakeholder groups on different stages of the project life cycle.

Research Design \& Methods: The paper builds on a larger research study looking at the development of the best practice framework for PPPs. The research is based on both a literature review and empirical studies. To examine the perception of critical success factors (CSFs) a questionnaire was conducted within different stakeholder groups for PPPs in Poland.
\end{abstract}

Findings: The article concentrates on one of the two dimensions of a PPP project success which is the idea of critical success factors. The research reveals that public and private parties do not share common perception of the PPP success. In general, the private sector assigns lower values to the CSFs analysed from the whole life perspective of a PPP project.

Implications \& Recommendations: The research indicates that the interpretation of a PPP project success depends of the stakeholders' role in the project. Future research might try to integrate a wider range of stakeholders engaged in PPPs such as financial institutions or a final user of the services provided under a PPP project.

Contribution \& Value Added: . The results of the study provides helpful information to identify areas that stakeholders should pay a special attention to in order to achieve the success of a PPP project.

\begin{tabular}{ll}
\hline Article type: & research paper \\
Keywords: & procurement; success; project management; critical success factors; \\
& public-private partnership; Poland
\end{tabular}

JEL codes: H11, L21, M19

Received: 2 February 2016 Revised: 25 April 2016 Accepted: 15 June 2016

\section{Suggested citation:}

Węgrzyn, J. (2016). The Perception of Critical Success Factors for PPP Projects in Different Stakeholder Groups. Entrepreneurial Business and Economics Review, 4(2), 81-92, DOI: http://dx.doi.org/10.15678/EBER.2016.040207 


\section{INTRODUCTION}

The idea of cooperation between public authorities and private institutions in order to meet the growing needs of society has been developing through centuries. During that time a wide range of solutions has been implemented. One of these forms could be regarded as public - private partnership (PPP). However, the PPP formula itself was popularised relatively recently, because just at the beginning of the 1990s. Since then, the advantages of adopting PPPs have been widely documented. The experience gained in the area of PPP clearly indicates that the main reasons for partnerships are risk sharing and the ability of the private sector to deliver, finance, maintain, and operate a project at lower costs than the public sector (Savas, 2000, p. 34).

Unfortunately, a number of PPP projects have been performing below the expected level. The expected outcomes of PPP projects could be affected by a number of factors and their interactions during a project life cycle. These factors differ from stakeholder perspectives and their respective definition of project performance (Mladenovic, Vajdic, Wündsch \& Temeljotov-Salaj,2013, p. 230).

Considering the growing interest in PPP performance, many areas of project management have been explored. In particular, researchers focused on the identification of critical success factors (CSFs) for PPPs.

The aim of this study is to identify and evaluate critical success factors at different stages of PPP projects. The main goal of the research is to increase understanding which factors are perceived as critical for the success of PPPs by different stakeholder groups on different stages of a project life cycle. The research would also help to identify the areas that PPP stakeholders should pay attention to in the future to achieve the success of a PPP project.

The article is divided into four main parts. Firstly, the theoretical assumptions on the project success are presented. The second part describes the methodology of the research. In the third part the results of the conducted tests are presented and discussed. Conclusions and recommendations for further research are presented in the final part of the article.

\section{LITERATURE REVIEW}

\section{Development of the Contemporary Concept of Public Private Cooperation}

As witnessed in the last few decades, PPP comes in many shapes and sizes. Most common PPPs are perceived as a tool of providing infrastructure investments. This type of arrangement is organised around a design, finance, built, own, operate, transfer model and involves the private sector financing and the private sector project management capabilities.

However, even with this wide adoption, the term "PPP" may indeed mean different things to different people. If this is the case, as G. Hodge and C. Greve ask, then how might we build on this idea and develop a conceptual model in order to contribute to multiple jurisdictions and PPP debates around the globe?

G. Hodge and C. Greve suggest that "perhaps it makes sense to view PPP as being understood at many different levels" (Hodge \& Greve, 2010). This idea can be formulated 
in the way described below. (1) We might firstly view PPP as a specific infrastructure project; (2) as a management or project delivery reform; (3) as a governmental policy; (4) more broadly as part of the strong and capable private sector in a mixed economy; (5) or more broadly again, as part of the modern governance task. In this model, each of the inner perspectives of PPP exists within the context of others (see: Węgrzyn, 2015).

In the present research, the author adopts the first approach. That means that PPP will be analysed from a single project perspective. The adopted research approach enables to analyse the PPP issues in the context of organisation theory.

\section{Polish Experience in PPP}

The implementation of PPP projects in Poland began as late as in 2009. It is generally believed that that was a result of new PPP legislation which came into force in the early 2009 (Szymankiewicz, 2013). At that time, under the rule of the new regulations, 425 procedures for private partner selection were reported (in Poland, according to law regulations, four forms of a project contribute to these statistics: (1) PPP under the Public Procurement Act, (2) PPP under the Concession for Constructions Works and Services Act, (3) concessions for construction works, (4) concessions for services). The vast majority of procedures (about 70\%) were announced by local governments (Nalepka \& Węgrzyn, 2015).

Although public-private partnerships in Poland are a relatively young and promising investment model, they are still poorly developed (Belniak, 2008; Wojewnik-Filipkowska \& Trojanowski, 2013; Śmiechowicz, 2014). By the end of 2012, only 105 out of all the procedures announced in the years 2009-2015 resulted in a private partner selection. This means that in $75 \%$ of cases these projects did not succeed. For comparison, in developing countries projects that failed (the proceedings were cancelled or the implementation of projects encountered financial difficulties) in the years 1990 to 2011 constituted less than $6.1 \%$ of the whole number of projects (based on the data about PPP projects carried out since 1990 by the World Bank, ppi.worldbank.org, access: 10.05.2013).

To cope with an increased number of PPP projects foreseeable in the near future, there is a strong need to study the practice of this method in Poland.

\section{An Analytical Approach to the Problem of the PPP Success Criteria}

The research model is built on several key ideas concerning the success of PPPs. Before these findings can be presented, a brief overview of the project success background needs to be established.

In the late 1960s, scholars, focusing on the operational side of project management, used to measure the success of a project in terms of cost, time and quality. In the 1980s they moved from the viewpoint of examining technical aspects of a project to focus on how the project is related to the client's organisation (Pinto \& Slevin, 1988, pp. 67-73). Since then, the literature started to recognize the importance of success and its interpretation by various groups of stakeholders. However, those studies were not equipped enough with a clear definition of stakeholders (Davies, 2013). The attempts to fill the gap were taken by Turner, Müller and Zolin (e.g. Turner \& Müller, 2006; Turner \& Zolin, 2012) when they undertook research to determine whether there was any collective understanding of success within groups.

Nowadays, the literature is perceived to be more stakeholder-focused with a project success being dependent on the project life cycle (short term goals) and not on the wider 
organisation (long term goals) (Turner \& Zolin, 2012, p. 90). This suggests a gap to examine how the organisation views a project, thus combining short and long term goal angles.

Thus, a project success may indeed mean different things to different groups of stakeholders. For example, Huxham and Hibbert (2008) studying what makes PPPs successful or not, indicated five types of the PPP success. Those are: (1) achieving outcomes, (2) getting the process work, (3) reaching emergent milestones, (4) gaining recognition from others, and (5) acknowledging personal pride in championing a partnership. Each of these alternative dimensions is valuable and each brings different PPP characteristics into the spotlight.

Having defined the term of the PPP success, we can indicate that researchers distinguish two components of a project success (Turner, 2009, p. 12). Those are: (1) success criteria - the dependent variables by which the successful outcome is being judged (2) and success factors - the independent variables that will influence the successful achievement of the success criteria.

Therefore, the issue of a project success can be perceived from two opposite perspectives. Taking into consideration the first perspective, the emphasis is put on the issues of integrating the project objectives and measurable results. In the other approach, researchers focus on the factors that promote the achievement of the objectives set by the project which are usually defined as success factors.

This research relates to the other approach. That is why, it is worth mentioning that the discussion on the "success factors" was started by D. R Daniel (1961, p. 111). Important contribution to the development of the CSF concept was brought by J. Rockart's (1979, p. 32) works. Rockart found that CSF was a key area for the manager's action, in which favourable results are absolutely necessary to achieve the desired goals.

According to Rockart, the CSF concept helps the manager to determine those factors on which he or she should focus the management attention. It also helps to ensure that those significant factors will receive careful and continuous management scrutiny. It also reveals that some factors are temporal and that CSFs are manager-specific.

The most recognisable classification of success factors was elaborated by Pinto and Slevin $(1987$, p. 70). The authors divided a project success factors into ten groups shown in Table 1.

The idea of the CSF analysis is also well documented in the literature on PPPs, (e.g. Jefferies, Gameson \& Rowlinson, 2002; Li, Akintoye, Edwards \& Hardcaslte, 2005; Tang, Shen, Skitmore \& Cheng, 2012; Cheung, Chan, Lam, Chan \& Ke, 2012).

Jefferies et al. (2002) examined the perceptions of BOOT schemes in order to develop a framework for critical success factors. Li et al. (2005) developed a list of 18 potential critical success factors (CSFs) for PPP/PFI construction projects in the UK. This 18 factors were divided into five groups: (1) effective procurement, (2) project implementability, (3) government guarantee, (4) favourable economic policy, (5) available financial market. The CSF concept has also been analysed at various stages within the PPP arrangement. For example, Tang et al. (2012) focused on the success factors at the briefing stages of PPP. The research contributes to the development of the best practice framework for PPPs. The attention has been given to developed, as well as developing countries employing the PPP policy to foster the infrastructure growth. 
Table 1. Pinto and Slevin's (1987) success factor list

\begin{tabular}{|l|l|}
\hline \multicolumn{1}{|c|}{ Success factor } & \multicolumn{1}{c|}{ Description } \\
\hline 1. Project mission & Clearly defined goals and direction \\
\hline 2. Top management support & Resources, authority and power for implementation \\
\hline 3. Schedule and plans & Detailed specification of implementation process \\
\hline 4. Client consultation & Communication with and consultation of all stakeholders \\
\hline 5. Personnel & Recruitment selection and training of competent personnel \\
\hline 6. Technical tasks & Ability of the required technology and expertise \\
\hline 7. Client acceptance & Selling the final product to the end users \\
\hline 8. Monitoring and feedback & Timely and comprehensive control \\
\hline 9. Communication & Provision of timely data to key players \\
\hline 10. Trouble-shooting & Ability to handle unexpected problems \\
\hline
\end{tabular}

Source: Pinto and Slevin (1987).

\section{MATERIAL AND METHODS}

All CSFs are regarded 'critical'. However, as some are more important than others, it is reasonable to attempt to rank them.

The aim of the study was to answer the following research questions:

1. Which of the CSFs are perceived as crucial factors of the PPP project success in Poland?

2. Is there a difference in the evaluation of CSFs, depending on the stage on which the PPP is being assessed?

3. Is there a difference in the evaluation of CSFs among various stakeholders of the project?

In order to identify relevant CSFs, a wide range of research methods can be used. Among them, the following ones can be listed: realisation of case studies, group interviews, structured interviews, as well as the analysis of the relevant literature. According to Osei-Kyei and Chan (2015, p. 1339), there are two popular methods that can be used to identify success factors for PPP: a case study and questionnaire surveys.

In this study the questionnaire template designed by Li et al. (2005) was adopted. The author used the Likert scale and presented a ranking of CSFs according to the assigned mean values for those factors.

There are two important advantages arising from adopting Li's survey questionnaire, rather than designing a new one. Firstly, the value of Li's questionnaire has already been widely recognised by the industry at large (Cheung et al. 2012, p. 649). Secondly, by administering Li's questionnaire in different administrative systems, it might be of interest for comparison purposes in the future.

That is why, the five-point Likert scale (1-least important and 5 - most important), as described previously, was used to calculate the mean score for each CSF, which was then used to determine its relative ranking in descending order of importance. These rankings made it possible to compare the relative importance of the CSFs to the previous research.

A comprehensive literature review that was conducted to study the CSFs of PPPs leads to the observation that it is also worth investigating separately the problem of success factors at the briefing stage of PPP projects. That is why, Li's questionnaire was divided 
into two stages - the first concerning CSFs at the briefing stage and the other concerning PPP in general (Li et al. 2005).

The questionnaire survey was administered in 2013 among organisations that have documented experience in PPP projects. As the data on the whole population of those organisations were not available, a purposive sample was chosen. The study was crosssectional in nature and included various PPPs' stakeholders from all over the country. The questionnaire was sent to 76 public sector entities which initiated the PPP proceedings and 90 respondents whose contact details were obtained at conferences, PPP training courses and from a webpage on PPP topics. 52 completed questionnaires were returned. The basic statistics concerning all the respondents are presented in Table 2.

Table 2. Survey respondents' roles in PFI/PPP projects

\begin{tabular}{|c|c|c|}
\hline Role & No & $\% *$ \\
\hline Central government & 4 & $8 \%$ \\
\hline Local government & 32 & $62 \%$ \\
\hline Government agency & 6 & $12 \%$ \\
\hline Public enterprise & 4 & $8 \%$ \\
\hline Public sector & 46 & $89 \%$ \\
\hline Financier & 7 & $13 \%$ \\
\hline Main contractor & 1 & $2 \%$ \\
\hline Designer & 1 & $2 \%$ \\
\hline Subcontractor & 0 & $0 \%$ \\
\hline Consultant/adviser & 14 & $27 \%$ \\
\hline Operator & 2 & $4 \%$ \\
\hline Supplier & 0 & $0 \%$ \\
\hline Private sector & 25 & $48 \%$ \\
\hline
\end{tabular}

*results do not sum to $100 \%$ because more than one answer was possible Source: own elaboration.

\section{RESULTS AND DISCUSSION}

The relative importance of the 18 CSFs was explored by means of Likert rating scale questions in the survey instrument. The analysis of the survey response data obtained from both public and private sector representatives produced mean importance values for CSFs ranging from 3.19 to 4.64 (Table 3).

An appropriate division of risks was ranked first in the survey analysis. The average rating of CSF is higher for the answers given by the public sector representatives. In the original Li research this CSF was ranked as the second most important factor for achieving successful PPP projects. This suggests that in Poland managers perceive, similar to other countries, appropriate risk sharing mechanisms as a crucial factor contributing to 
Table 3. Survey respondents' perceptions of the relative importance of CSFs for PPP projects on the basis of the questionnaire template designed by Li (2003)

\begin{tabular}{|c|c|c|c|c|c|c|c|c|c|c|c|c|c|c|}
\hline \multirow{3}{*}{\multicolumn{2}{|c|}{ CSF }} & \multirow{3}{*}{ Group } & \multicolumn{4}{|c|}{ Total } & \multicolumn{4}{|c|}{ Public sector } & \multicolumn{4}{|c|}{ Private sector } \\
\hline & & & \multicolumn{2}{|c|}{$\begin{array}{l}\text { Selecting } \\
\text { priv. part. }\end{array}$} & \multicolumn{2}{|c|}{$\begin{array}{l}\text { Whole life } \\
\text { approach }\end{array}$} & \multicolumn{2}{|c|}{$\begin{array}{c}\text { Selecting } \\
\text { private part. }\end{array}$} & \multicolumn{2}{|c|}{$\begin{array}{l}\text { Whole life } \\
\text { approach }\end{array}$} & \multicolumn{2}{|c|}{$\begin{array}{c}\text { Selecting } \\
\text { private part. }\end{array}$} & \multicolumn{2}{|c|}{$\begin{array}{l}\text { Whole life } \\
\text { approach }\end{array}$} \\
\hline & & & Mean & No & Mean & No & Mean & No & Mean & No & Mean & No & Mean & No \\
\hline 1 & Transparent procurement process & \multirow{7}{*}{$\begin{array}{c}\text { effective } \\
\text { procurement }\end{array}$} & 4.56 & 4 & 4.14 & 7 & 4.61 & 3 & 4.26 & 7 & 4.40 & 6 & 3.73 & 8 \\
\hline 2 & Competitive procurement process & & 4.00 & 9 & 3.81 & 11 & 4.10 & 8 & 3.94 & 10 & 3.73 & 12 & 3.40 & 12 \\
\hline 3 & Good governance & & 4.02 & 8 & 4.06 & 8 & 3.97 & 9 & 4.19 & 8 & 3.93 & 9 & 3.67 & 10 \\
\hline 4 & $\begin{array}{l}\text { Well-organised and committed public } \\
\text { agency }\end{array}$ & & 3.31 & 17 & 3.37 & 16 & 3.26 & 18 & 3.45 & 16 & 3.07 & 17 & 3.00 & 17 \\
\hline 5 & Social support & & 3.83 & 12 & 3.89 & 10 & 3.74 & 13 & 3.77 & 13 & 4.13 & 8 & 4.00 & 6 \\
\hline 6 & $\begin{array}{l}\text { Shared authority between the public } \\
\text { and private sector }\end{array}$ & & 4.54 & 5 & 4.54 & 3 & 4.61 & 4 & 4.55 & 4 & 4.53 & 4 & 4.33 & 2 \\
\hline 7 & $\begin{array}{l}\text { Thorough and realistic cost/benefit } \\
\text { assessment }\end{array}$ & & 4.62 & 2 & 4.42 & 4 & 4.71 & 1 & 4.58 & 3 & 4.67 & 2 & 4.33 & 1 \\
\hline 8 & Project technical feasibility & \multirow{5}{*}{$\begin{array}{c}\text { project } \\
\text { implementa- } \\
\text { bility }\end{array}$} & 3.19 & 18 & 3.19 & 18 & 3.42 & 16 & 3.48 & 15 & 2.80 & 18 & 2.93 & 18 \\
\hline 9 & Appropriate risk allocation /sharing & & 4.64 & 1 & 4.65 & 1 & 4.65 & 2 & 4.77 & 1 & 4.80 & 1 & 4.27 & 3 \\
\hline 10 & $\begin{array}{l}\text { Commitment/responsibility of } \\
\text { public/private sectors }\end{array}$ & & 4.58 & 3 & 4.54 & 2 & 4.61 & 5 & 4.71 & 2 & 4.67 & 3 & 4.07 & 4 \\
\hline 11 & Strong and good private consortium & & 3.96 & 10 & 3.79 & 12 & 3.94 & 10 & 3.87 & 11 & 3.93 & 10 & 3.60 & 11 \\
\hline 12 & Favourable legal framework & & 4.42 & 6 & 4.35 & 5 & 4.45 & 6 & 4.48 & 5 & 4.33 & 7 & 4.07 & 5 \\
\hline 13 & $\begin{array}{l}\text { Government involvement by providing } \\
\text { guarantees }\end{array}$ & \multirow{3}{*}{$\begin{array}{l}\text { government } \\
\text { guarantee }\end{array}$} & 3.46 & 16 & 3.21 & 17 & 3.42 & 17 & 3.26 & 18 & 3.47 & 16 & 3.07 & 16 \\
\hline 14 & Multi-benefit objectives & & 3.71 & 14 & 3.67 & 13 & 3.71 & 14 & 3.84 & 12 & 3.67 & 15 & 3.27 & 15 \\
\hline 15 & Political support & & 3.64 & 15 & 3.44 & 15 & 3.52 & 15 & 3.42 & 17 & 3.80 & 11 & 3.33 & 13 \\
\hline 16 & Stable macro-economic conditions & \multirow{2}{*}{$\begin{array}{l}\text { favourable } \\
\text { econ. cond. }\end{array}$} & 3.89 & 11 & 3.98 & 9 & 3.94 & 11 & 4.07 & 9 & 3.73 & 13 & 3.73 & 9 \\
\hline 17 & Sound economic policy & & 3.77 & 13 & 3.52 & 14 & 3.81 & 12 & 3.71 & 14 & 3.73 & 14 & 3.33 & 14 \\
\hline 18 & Available financial market & & 4.40 & 7 & 4.25 & 6 & 4.39 & 7 & 4.42 & 6 & 4.47 & 5 & 3.73 & 7 \\
\hline
\end{tabular}

Source: own elaboration. 
the PPP success. However, in Li's research a strong private consortium has been revealed as most important CSF. Surprisingly, this factor in Poland was scored on the 10th position. This could be an effect of the PPP market specificity. In the UK these are mainly large and well established construction companies which have won PFI contracts, whereas in Poland PPP projects are rather small and obtain attention rather from local and regional investors. Although all the CSFs are nominally considered to be 'critical', the factors that are grouped under the category: government support are not perceived to be so important as other factors. Additionally, three factors are regarded less important for a project success: project technical feasibility, well-organised and committed public agency and multi-benefit objectives. This results are comparable with regard to the answers obtained from public and private representatives.

Taking a general view on the CSF ranking list, it indicates that the respondents share a similar opinion on a relative importance of the PPP success factors. However, a closer analysis of the data may reveal important differences.

That is why, to find out whether these disparities exist, it was decided to adopt nonparametric methods. To determine if there is a statistically significant association between categorical survey responses, Wilcoxon signed rank test and Mann - Whitney $U$ test can be used (see e.g. Meek, Ozgur, \& Dunning, 2007). The chosen tests are based on ranking methods, that is, methods in which scores $1,2,3 \ldots n$ are substituted for the actual data in order to obtain a rapid approximate idea of the significance of the differences in the experiments (Wilcoxon, 1992, p. 196).

The following research problem concerns the potential differences between the CSFs depending on the stage of a PPP project. It needs to be highlighted that a given rank to each CSF depends on the stage of a PPP project on which this factor is the subject of assessment. That is why, it is reasonable to aggregate observations in pairs. The appropriate method to test the significance of differences of the means in this case is Wilcoxon signedrank test. The summary of the results is included in Table 4.

Table 4. Summary of results for the Wilcoxon signed-rank test; $\alpha=0.05$

\begin{tabular}{|l|c|c|c|}
\hline \multicolumn{1}{|c|}{ Variable / Measure } & Total & $\begin{array}{c}\text { Public } \\
\text { sector }\end{array}$ & $\begin{array}{c}\text { Private } \\
\text { sector }\end{array}$ \\
\hline Wilcoxon test $T=\min \left\{\sum+, \sum-\right\}$ & $22.5^{* *}$ & 84 & $2 * *$ \\
\hline Efficient range of the sample $n$ & 16 & 18 & 17 \\
\hline Critical value for $\alpha=0.05$ & 30 & 40 & 35 \\
\hline
\end{tabular}

Source: own elaboration.

Wilcoxon test proves that significant differences between the mean evaluation of CSFs can be indicated in the whole group of respondents and in the group of private sector representatives. However, considering the obtained data for the public sector separately, it is suggested that the assessment given to each CSF does not depend on the project stage. These results indirectly indicate that these two parties may not share a common perception on PPP projects success or at least the project success criteria.

This leads us to the third research problem: whether any differences can be indicated in the evaluation of CSFs among various stakeholder groups of the PPP project. 
In this case the analysis is concentrated on the potential disparities within the data distributions obtained from representatives of the public and the private sector. This research perspective justifies an assumption that all the observations from both groups are independent of each other. That is why to answer this research question Mann - Whitney $U$ test was adopted (Nachar, 2008, p. 13). The results are presented in Table 5.

Table 5. Summary of results for the Mann - Whitney $U$ test, $\alpha=0.05$

\begin{tabular}{|c|c|c|c|}
\hline \multirow[b]{2}{*}{ Variable / Measure } & & \multicolumn{2}{|c|}{ Stages of PPP project } \\
\hline & & $\begin{array}{l}\text { Selecting private } \\
\text { partner }\end{array}$ & $\begin{array}{l}\text { Whole life } \\
\text { approach }\end{array}$ \\
\hline Sum of ranks for public sector & $R 1$ & 341 & 403 \\
\hline Sum of ranks for private sector & $R 2$ & 325 & 263 \\
\hline Mann-Whitney U statistic & $U$ & 154 & 92 \\
\hline Mean value & $E(U)$ & \multicolumn{2}{|c|}{162} \\
\hline Standard deviation & $\sigma_{v}$ & \multicolumn{2}{|c|}{31.607} \\
\hline Z statistic & $Z$ & -0.253 & $-2.215^{* *}$ \\
\hline
\end{tabular}

Source: own elaboration.

The obtained data indicate that the null hypothesis that two samples have the same distributions cannot be rejected when we are considering the differences in the perception of CSFs on the initial stage of PPP. This difference becomes more clear when the assessment is concentrated on the whole life of a PPP project. In this situation the ranks given by the public sector representatives are higher than the rates obtained from the private sector.

\section{CONCLUSIONS}

In conclusion, this paper has presented an analytical approach to the assessment of a project success and the success criteria. As many scholars point out, there still exists a need for research in this area to overcome the lack of clarity when defining success and stakeholder impact (the perceived importance of a project success factors by different stakeholder groups) (Davies, 2014, p. 11). That is why, theoretical considerations were supported by empirical research on CSFs for PPP in Poland.

In answering the research questions, the analysis revealed that public and private parties had most in common in perceiving a relative importance of a project success on the initial stage of a PPP project. The research, however, identified some disparities in the evaluation of CSFs. The main issue highlighted was that when we are looking at the PPP project from the whole life perspective, the mean score values of responses given to each CSF are becoming divergent. Generally, the private sector assigns lower values to the CSFs analysed from the whole life perspective of the PPP project.

The fact that along with the implementation of a PPP project there may occur discrepancies in the perception of the project success, has important practical implications. The essence of PPP can be summarised as long-term commitment between the public and private sector entities to deliver an expected infrastructure service. That is why, to avoid any possible discrepancies in this process, appropriate measures should be taken at the initial stage of the project and it should find its expression in the contract. 
The limitation of this research is that only two groups of stakeholders were taken into consideration. It is recommended to conduct future studies on a wider range of stakeholders engaged in PPPs, such as financial institutions or a final user of the services provided under a PPP project.

To sum up, the stress in the research was put on the factors that are critical to a PPP project success. Future studies may wish to explore more focused CSF templates as a device to clarify success factor relationships.

\section{REFERENCES}

Belniak, S. (2008). A partnership of public and private sectors as a model for the implementation of urban revitalization projects. Journal of European Real Estate Research, 1(2), 139-150, DOI: 10.1108/17539260810918712

Cheung, E., Chan, A.P.C, Lam, P.T.I., Chan, D.W.M., \& Ke, Y. (2012). A comparative study of critical success factors for public private partnerships (PPP) between Mainland China and the Hong Kong Special Administrative Region, Facilities, 30(13), 647 - 666, DOI: 10.1108/02632771211273132

Daniel, D.R. (1961). Management Information Crisis, Harvard Business Review, 39(5),111-116.

Davis, K. (2014). Different stakeholder groups and their perceptions of project success. International Journal of Project Management, 32(2), 189-201, DOI:10.1016/ j.ijproman.2013.02.006

Li, B., Akintoye, A., Edwards, P.J., \& Hardcaslte, C. (2005). Critical success factors for PPP/PFI projects in the UK construction industry, Construction Management and Economics, 23, 459-471, DOI: 10.1080/01446190500041537

Hodge, G., \& Greve, C. (2010). Public-Private Partnerships: Governance Scheme or Language Game? The Australian Journal of Public Administration, 69, 8-22, DOI: 10.1111/j.1467-8500.2009.00659

Huxham, C., \& Hibbert, P. (2008). Hit or myth? Stories of collaborative success. In J. O’Flynn \& J. Wanna (Eds.), Collaborative Governance: A New Era of Public Policy in Australia? Canberra: ANU E Press, 45-51.

Jefferies, M., Gameson, R., \& Rowlinson, S. (2002). Critical success factors of the BOOT procurement system: reflections from the Stadium Australia case study, Engineering Construction and Architectural Management, 9(4), 352-361, DOI: 10.1046/j.1365-232X.2002.00249

Meek, G.E., Ozgur, C., \& Dunning, K. (2007). Comparison of the t vs. Wilcoxon signed-rank test for Likert scale data and small samples. Journal of Modern Applied Statistical Methods, 6(1), 91106.

Mladenovic, G., Vajdic, N., Wündsch, B., \& Temeljotov-Salaj, A. (2013). Use of key performance indicators for PPP transport projects to meet stakeholders' performance objectives. Built Environment Project and Asset Management, 3(2), 228-249, DOI: http://dx.doi.org/10.1108/ BEPAM05-2012-0026

Nachar, N. (2008). The Mann-Whitney U: A test for assessing whether two independent samples come from the same distribution. Tutorials in Quantitative Methods for Psychology, 4(1), 13-20.

Nalepka, A., \& Węgrzyn, J. (2015). Rola projektów partnerstwa publiczno-prywatnego w realizacji strategii gminy. Turystyka i Rozwój Regionalny, 3, 89-99.

Osei-Kyei, R., \& Chan, A.P. (2015). Review of studies on the Critical Success Factors for Public-Private Partnership (PPP) projects from 1990 to 2013. International Journal of Project Management, 33(6), 1335-1346, DOI: 10.1016/j.ijproman.2015.02.008 
Pinto, J.K., \& Slevin, D.P. (1988). Project success: definitions and measurement techniques. Project Management Journal, 19(1), 67-73.

Rockart, J. (1979). Chief Executives Define Their Own Information Needs. Harvard Business Review, March/April, 81-92.

Szymankiewicz, M.J. (2013). Collaborative Advantage in Public and Social Services: the Case of Poland. Entrepreneurial Business and Economics Review, 1(4), 71-81; http://dx.doi.org/ 10.15678/EBER.2013.010406

Savas, E.S. (2000). Privatization and Public - Private Partnerships, , New York: Seven Bridges Press LCC.

Śmiechowicz, J. (2014). Wykorzystanie środków europejskich w realizacji projektów partnerstwa publiczno-prywatnego w Polsce-doświadczenia i perspektywy. Zeszyty Naukowe Wyższej Szkoły Bankowej w Poznaniu, 57(6), 31-42.

Tang, L., Shen, Q., Skitmore, M., \& Cheng, E.W. (2012). Ranked critical factors in PPP briefings. Journal of Management in Engineering, 29(2), 164-171, DOI: 10.1061/(ASCE)ME.19435479.0000131

Turner, J.R. (2009). The Handbook of Project-based Management: Leading Strategic Change in Organizations. New York: McGraw-Hill Education.

Turner, J.R., \& Müller, R. (2006). Choosing Appropriate Project Managers: Matching their Leadership Style to the Type of Project., Newtown Square: Project Management Institute.

Turner, J.R., \& Zolin, R. (2012). Forecasting success on large projects: developing reliable scales to predict multiple perspectives by multiple stakeholders over multiple time frames. Project Management Journal 43 (5), 87-99; DOI: 10.1002/pmj.21289

Węgrzyn, J. (2015). Research Trends of Public-Private Partnerships (PPPs) in Poland. Oeconomia Copernicana, 6 (1), 125-136, DOI: http://dx.doi.org/10.12775/OeC.2015.007

Wilcoxon, F. (1992). Individual comparisons by ranking methods. In: S. Kotz, N. Johnson (Eds.), Breakthroughs in Statistics: Methodology and Distribution (pp. 196-202). New York: Springer.

Wojewnik-Filipkowska, A., \& Trojanowski, D. (2013). Principles of public-private partnership financing-Polish experience. Journal of Property Investment \& Finance, 31(4), 329-344, DOI: http://dx.doi.org/10.1108/JPIF-10-2012-0049 


\section{Author}

\section{Joanna Węgrzyn}

Assistant professor at the Cracow University of Economics - Department for Economics of Real Estate and Investment. Her scientific interests focus on the issues of infrastructure, project management and public management.

Correspondence to: Joanna Węgrzyn, PhD, Cracow University of Economics, Faculty of Economics and International Relations, Department for Economics of Real Estate and Investment, 31-510 Kraków, ul. Rakowiecka 27, Poland, e-mail: wegrzynj@uek.krakow.pl

\section{Acknowledgements and Financial Disclosure}

The article came into being within the statutory research project no. 052/WEKEN/01/2015/S/5052entitled "Current problems of preparation and implementation of investment projects" coordinated by A. Nalepka and financed by the Ministry of Science and Higher Education of the Republic of Poland with the funds allocated to development of research potential of the Faculty of Economics and International Relations of the Cracow University of Economics.

The authors would like to thank the anonymous referees for their useful comments, which allowed to increase the value of this article.

\section{Copyright and License}

This article is published under the terms of the Creative Commons Attribution - NonCommercial - NoDerivs (CC BY-NC-ND 3.0) License http://creativecommons.org/licenses/by-nc-nd/3.0/ 